\title{
EFFECT OF FIRES ON CERTAIN PROPERTIES OF FOREST SOILS IN WESTERN ALGERIA
}

\author{
Ayoub ALLAM ${ }^{1 *}$, Amine Habib BORSALI ${ }^{1}$, Abdelkrim KEFIFA ${ }^{1}$, Mohamed ZOUIDI ${ }^{1}$, Raphael GROS ${ }^{2}$ \\ ${ }^{1}$ University of Dr Moulay Tahar, Saïda, Algeria \\ ${ }^{2}$ Aix-Marseille University, Marseille Cedex, France
}

\begin{abstract}
Natural disturbances, such as forest fires, cause significant changes in the structure and functioning of semi-arid ecosystems. After such disturbances, the impact on the soil ecosystem in its entirety is misunderstood. In this study, two years after the last fire, changes in the physicochemical and biological properties of Aleppo pine forest soils in the semi-arid zone were observed. Among all physical properties analysed, only the soil moisture remained significantly lower in the burnt zone in contrast to control zone. Considering the chemical properties, the only negatively affected parameter is the rate of organic matter. In terms of biological properties, results showed that the fire caused a significant decrease in soil microorganisms by decreasing basal respiration and microbial biomass. Conversely, the metabolic quotient recorded higher values in the fire zone than in the control zone. These results indicate that microbial communities in semi-arid soils, already stressed by climatic hazards, are very sensitive to the passage of even low-intensity fires.
\end{abstract}

Keywords: degradation; organic matter; microbial biomass; semi-arid regions

The forest ecosystems of the Mediterranean basin contain remarkable biodiversity, providing important economic resources in terms of sylvo-pastoral production, as well as tourism and leisure areas. Furthermore, they also provide essential ecosystem services, e.g. water erosion reduction by the retention of water in the soil (Eamus et al., 2005). Drought is one of the most unfavourable and most common constraints in arid and semi-arid regions (Sabaghnia and Janmohammadi, 2014), and the presence of pyrophyte species in these regions, such as Cistus (Cistus ladaniferus) or Aleppo Pine (Pinus halepensis Mill), can promote fires (Borsali, 2013). Soil degradation by any means represents one of the most significant issues in terms of maintaining the soil quality (Nouraein et al., 2020).

Numerous authors confirm that the origins of fire are mainly related to humans and directly depend on imprudence and insouciance of people, especially in terms of the agricultural and pastoral utilization of land (Meddour, 2014). According to the statistics provided by the Direction General of Forests, Algeria is seriously affected by fires, especially the north of the country. In 2017, the total area burnt by fires was 51,908 ha. Due to the significant evolution of this disaster and observed damage on the forest ecosystem, it is highly recommendable to investigate the changes in properties of these burnt soils.

Certini (2005) synthesizes the effects of fire on the properties of forest soils and shows that the main factor is the severity of fire, which depends on the environmental factors involved in the combustion processes: quantity; nature and moisture of the dead and living combustible; wind speed; and site topography. This severity depends on two factors: the intensity and duration of the fire. High intensity combined with a long duration of fire would cause the greatest damage to vegetation and soil. The decline in soil protection leads to lower stability and, as a result, increased vulnerability to erosion risk (Hart et al., 2005).

The increase in the number of fires and their frequency have reduced the time between the two successive fires to less than 20 years (Vennetier et al., 2008). Their effects on soil biology are both direct - instantaneous destruction of organisms living on the surface - and indirect - environment modification (soil, vegetation cover) (Uroz et al., 2014). In addition to their effect on physicochemical parameters, fires also directly or indirectly affect the soil organisms. Direct effects induce short-term changes that modify species composition and abundance of taxonomic groups (Gongalsky et al., 2012).

Algerian soils are naturally vulnerable, sometimes highly degraded, especially in the semi-arid zone. These soils are highly affected by the issue of forest fires and their impact on soils is not very investigated by scientists. In addition, the difficulty of returning to an optimal performance level after fire must be enlightened by an objective evaluation of the short-term return dynamics of these soil properties. In order to answer the most significant questions related to the state of Algerian post-fire soils, a comparative study of selected physicochemical and biological parameters of a soil after two years of the last fire and a control soil that did not undergo fire for twenty years was carried out. 


\section{Material and methods}

\section{Study area}

The study area is in the semi-arid bioclimatic stage of Ouled Khaled Saïda. This private forest, known as Keroua, is located between ( $34^{\circ} 54^{\prime}$ $55.00^{\prime}, \mathrm{N} 0^{\circ} 7^{\prime} 29.14^{\prime \prime} \mathrm{E}$ ). It covers an area of 760 ha (Fig. 1).

This bioclimatic domain receives $345.16 \mathrm{~mm}$ of precipitation with a seasonal rainfall regime of winter, spring, summer and autumn (WSSA). According to the Saïda Meteorological Station (SMS, 2017), the maximum average temperature is $24.6{ }^{\circ} \mathrm{C}$; the minimum average temperature is $11^{\circ} \mathrm{C}$ and the thermal average amplitude is $19.9^{\circ} \mathrm{C}$. In the observed area, the number of fires for the period from 1999 to 2016 is 190 in total, which destroyed a total forest area of 3,355.25 ha. This corresponds to an annual average of 10.56 fires and 186.40 ha of burnt area. The number of fires varies from year to year - in 2007, fires burnt the smallest area of 9 ha, and in 1999 an absolute
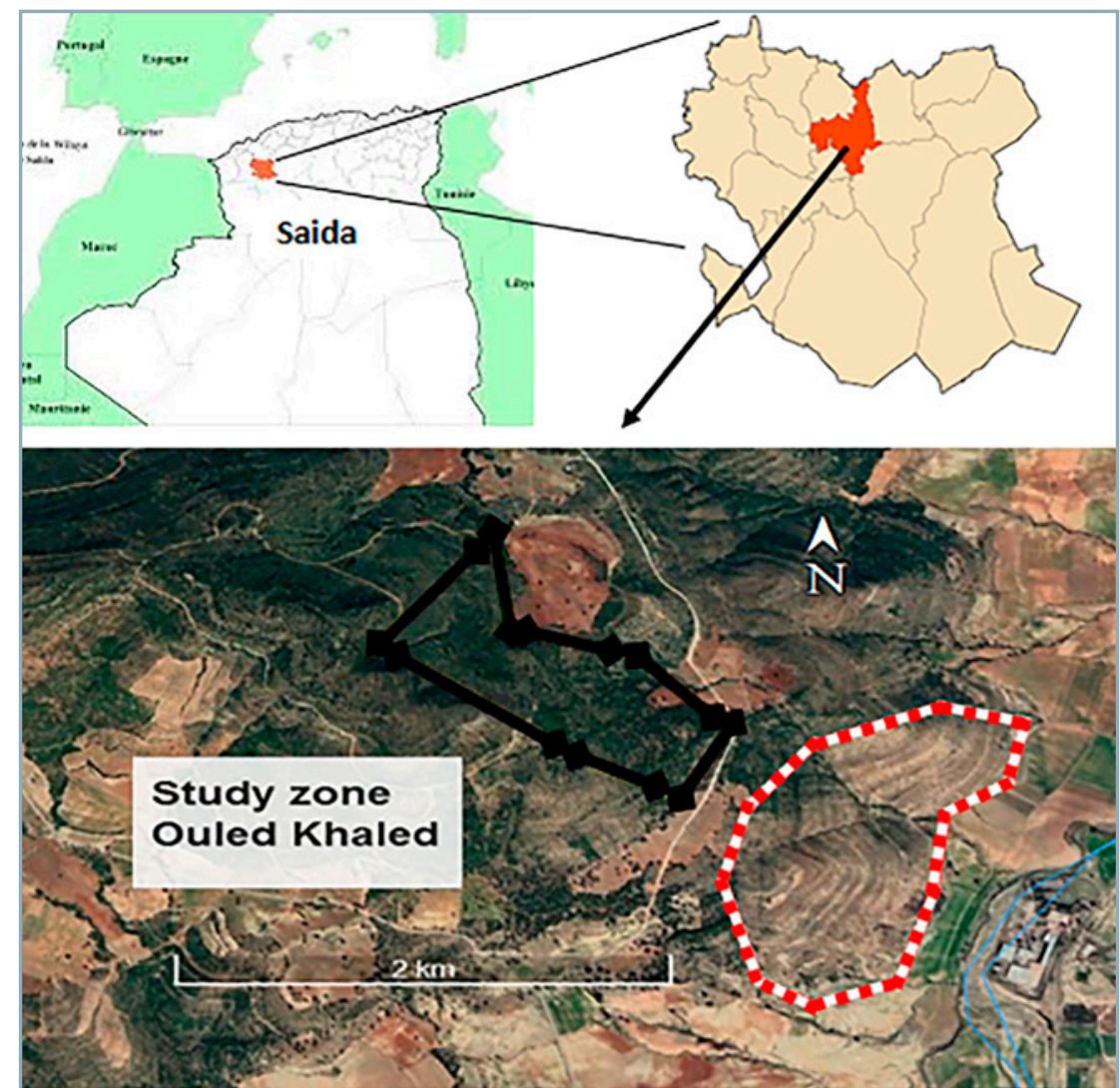

Control zone

Burned zone maximum of $1,160.5$ ha, while in 2015 , only a small number of fires (9) was recorded, yet a total forest area of 720.75 ha was destroyed as a result.

The plots used for control measurements are in the same area but were not affected by fires for at least twenty years. This zone is characteristic with good density of vegetal cover dominated mainly by the Aleppo Pine and different plant strata.

\section{Methodology and soil sampling}

The study of the fire effects on the soil properties required determination of an appropriate methodology with the thematic, for that, the following criteria were respected:

1. the forest cover in observed zone was to predominantly compose of a monospecific population of Aleppo pine;

2. the control zone must be at least by $50 \mathrm{~m}$ away from the fire border;

3. the analysis is conducted two years after the fire that was recorded in 2015. Thus, the plots were visited in . spring of 2017 for the collection of soil samples.

In each zone (burnt and control), five plots were randomly selected. Soil samples were taken from the first horizon with a depth of $0-10 \mathrm{~cm}$, sieved to particle size of $2 \mathrm{~mm}$ at maximum and conditioned in cold for biological analysis.

\section{Physical analysis}

Soil moisture content (d.b.) was determined by weighing a certain amount of soil before and after drying in an oven at $105^{\circ} \mathrm{C}$ for $24 \mathrm{~h}$. The soil mass loss represents the mass of water evaporated during drying (Mathieu and Pieltain, 1998). The soil moisture content was determined as follows:

$$
u=\left(\frac{m_{B 2}-m_{B 3}}{m_{B 3}-m_{B 1}}\right) 100(\%)
$$

where:

$u$ - soil moisture content $(\%) ; m_{B 1}-$ mass of empty breaker $(\mathrm{g}) ; m_{B 2}-$ mass of breaker + fresh soil $(5 \mathrm{~g}) ; m_{B 3}-$ mass of breaker + dried soil $(\mathrm{g})$

Soil permeability is given by the height of water measured per centimetre of infiltration per unit of time (Mathieu and Pieltain, 1998).

The samples were placed in graduated cylinders up to $100 \mathrm{ml}$, which are then filled with distilled water up to $200 \mathrm{ml}$. Subsequently, it is left resting for $12 \mathrm{~h}$, and after it, the water height is measured. Permeability is defined as follows:

$$
K=0.857 \cdot h
$$

where:

$K$ - permeability $\left(\mathrm{cm} \cdot \mathrm{h}^{-1}\right) ; h$ - water height $(\mathrm{cm})$

The soil sample is moistened for $12 \mathrm{~h}$ by capillary rise in a sintered glass Buchner filter. Then, the filter is placed on a vacuum flask connected to a water pump to remove water in pores with a diameter less than $8 \mu \mathrm{m}$. The retention capacity $(R C)$ is defined as the water content remaining in the soil after $24 \mathrm{~h}$ (Saetre, 1998). It was calculated according to the following formula:

$R C=\left[\frac{\left(m_{B 2}-m_{B 1}\right)-\left(m_{B 3}-m_{B 1}\right)}{\left(m_{B 3}-m_{B 1}\right)}\right] 100$ (\%) (3)

Fig. 1 Location of the observed zone 
where:

$R C$ - retention capacity (\%); $m_{B 1}$ - empty filter mass (g); $m_{B 2}$ - filter mass with moistened soil for $12 \mathrm{~h}(\mathrm{~g}) ; m_{B 3}$ - mass of (filter + moist soil) after drying for $24 \mathrm{~h}$ at $105^{\circ} \mathrm{C}(\mathrm{g})$

The bulk density $(\rho v)$ corresponds to the dry mass of a soil volume, the structure of which has not been disturbed, knowing the constant dry mass of the sample at $105^{\circ} \mathrm{C}$ and the volume of the cylinders used (Blake and Hartge, 1986). Bulk density was calculated according to the following formula:

$$
\rho v=\frac{m_{B}}{V}
$$

where:

$\rho v$ - bulk density $\left(\mathrm{g} \cdot \mathrm{cm}^{-3}\right) ; m_{B}$ - dry soil mass $(\mathrm{g}) ; V$ - cylinder volume $\left(\mathrm{cm}^{3}\right)$

$$
V=\pi \cdot r^{2} \cdot h
$$

where:

$\pi-3.14 ; r$ - cylinder radius $(\mathrm{cm}) ; h-$ cylinder height $(\mathrm{cm})$

The measurement of the real density $(\rho)$ was determined by the pycnometer method, which consists of determining the volume of benzene displaced by the solid phase of sample with a known mass in a known volume (Pétard, 1993). The real density was obtained as follows:

$$
\begin{gathered}
\rho=\frac{m_{B}}{V} \\
V=\frac{\left(m_{B 1}+m_{B}\right)-m_{B 2}}{\rho_{B}}
\end{gathered}
$$

where:

$\rho$ - real density $\left(\mathrm{g} \cdot \mathrm{cm}^{-3}\right) ; m_{B}-10 \mathrm{~g}$ of soil dried in oven at $105{ }^{\circ} \mathrm{C}(\mathrm{g}) ; V$ - volume of used soil $\left(\mathrm{cm}^{3}\right) ; m_{B 1}$ - mass of pycnometer filled with benzene up to the mark $(\mathrm{g}) ; m_{B 2}-$ mass of pycnometer with $10 \mathrm{~g}$ of soil filled with benzene up to the mark after the disappearance of air bubbles (g); $\rho_{B}$ - benzene density $\left(\mathrm{g} \cdot \mathrm{cm}^{-3}\right)$

The porosity was determined by the following formula:

$$
p=\left(\frac{\rho-\rho v}{\rho}\right) 100(\%)
$$

where:

$p$ - porosity; $\rho$ - real density $\left(\mathrm{g} \cdot \mathrm{cm}^{-3}\right) ; \rho v$ - bulk density $\left(\mathrm{g} \cdot \mathrm{cm}^{-3}\right)$

The soil electrical conductivity measurement was performed by a conductivity meter HI2300, (HANNA Instruments, Italy) using a ratio of $20 \mathrm{~g}$ of dried fine soil in the open air and $50 \mathrm{ml}$ of distilled water (Paycheng, 1980).

\section{Chemical analysis}

The measurement of the $\mathrm{pH}_{\mathrm{H}_{2} \mathrm{O}}$ and $\mathrm{pH}_{\mathrm{KCl}}$ of the soil is an empirical measurement. For the measurement of $\mathrm{pH}_{\mathrm{H}_{2} \mathrm{O}}$ $20 \mathrm{~g}$ of fine soil dried in the open air were mixed in a beaker with $50 \mathrm{ml}$ of distilled water. For the measurement of $\mathrm{pHKCl}$, $20 \mathrm{~g}$ of soil and $50 \mathrm{ml}$ of potassium chloride were mixed in separate beaker (Paycheng, 1980). The measurements were conducted using a pH meter HI2210 (HANNA Instruments, Italy).

Total limestone $\left(\mathrm{CaCO}_{3}\right)$ was estimated by the Bernard calcimeter. This method allows the measurement of the volume of $\mathrm{CO}_{2}$ released by the soil samples under the action of hydrochloric acid $(\mathrm{HCl})$. The total limestone was calculated using the following expression:

$$
T L=\left[\left(\frac{V_{1}}{m_{B 1}}\right)\left(\frac{m_{B}}{V}\right)\right] 100(\%)
$$

where:

$T L$ - total limestone (\%); $m_{B}$ - reference sample mass $\left(\mathrm{CaCO}_{3}=1 \mathrm{~g}\right) ; m_{B 1}$ - mass of soil samples $(1 \mathrm{~g}) ; V$ - volume generated by reference sample $\left(V=225 \mathrm{~cm}^{3}\right) ; V_{1}$ - volume generated by soil samples $\left(\mathrm{cm}^{3}\right)$

The organic matter $(O R)$ was determined by mass loss of dry sample after the calcination at $550{ }^{\circ} \mathrm{C}$ for $16 \mathrm{~h}$. It was calculated using the following formula:

$$
O R=\left[\frac{\left(m_{B 1}-m_{B}\right)-\left(m_{B 2}-m_{B}\right)}{\left(m_{B 1}-m_{B}\right)}\right] 100(\%)
$$

where:

$O R$ - organic matter (\%); $m_{B}$ - empty breaker mass (g); $m_{B 1}$ - breaker mass with dried soil $(\mathrm{g}) ; m_{B 2}$ - breaker mass with calcined soil $(\mathrm{g})$

\section{Biological analysis}

Basal respiration (BR) was measured according to the protocol described by Anderson and Domsch (1978) to assess the physiological status of soil microbial communities. Ten grams (dry equivalent) of fresh soil kept at $4{ }^{\circ} \mathrm{C}$ were weighted in a glass phial $(117 \mathrm{ml})$. The phials were hermetically sealed with a plug immediately after the replacement (4 $\mathrm{min}$ ) of their internal atmosphere by a stable $\mathrm{CO}_{2}$ concentration atmosphere and incubated for $4 \mathrm{~h}$ at $25^{\circ} \mathrm{C}$. After incubation, an aliquot of phial atmosphere $(1 \mathrm{ml})$ was injected using a syringe into a gas chromatograph (Chrompack CHROM3 $\mathrm{CP}$ 9001). Ambient $\mathrm{CO}_{2}$ concentrations were subtracted from the $\mathrm{CO}_{2}$ concentrations measured after incubation to obtain the amount of $\mathrm{CO}_{2}$ produced by the heterotrophic microorganisms contained in the sample.

Microbial biomass (MB) was estimated using substrateinduced respiration (SIR) rates (Anderson and Domsch, 1978). Ten grams (dry mass equivalent) of sub-samples were placed in $117 \mathrm{ml}$ glass jars and amended with powdered glucose $\left(1,000 \mu \mathrm{gC} \cdot \mathrm{g}^{-1}\right)$. One millilitre of air was sampled in the head space with a syringe and injected into a gas chromatograph (Chrompack CHROM 3 - CP 9001). SIR rates were converted to microbial biomass value using the equation given by Beare et al. (1990). 
The metabolic quotient $\left(q \mathrm{CO}_{2}\right)$ was calculated as follows (Anderson and Domsch, 1978):

$$
q \mathrm{CO}_{2}=\frac{B R}{M B}
$$

where:

$q \mathrm{CO}_{2}$ - metabolic quotient (mg C-CO $\left.\cdot(\mathrm{g} \mathrm{Cmic})^{-1} \cdot \mathrm{h}^{-1}\right)$; $B R$ - basal respiration $\left(\mu \mathrm{gC}-\mathrm{CO}_{2} \cdot \mathrm{g}^{-1} \mathrm{DM} \cdot \mathrm{h}^{-1}\right) ; \mathrm{MB}-$ microbial biomass ( $\left.\mu \mathrm{gCmic} \cdot \mathrm{g}^{-1} \mathrm{DM}\right)$

\section{Statistical analysis}

Collected data were analysed using the Minitab 17 software (Minitab, LLC, company, United States). The 5\% threshold comparison test was used to compare the averages (student's test). The thresholds of significance considered are: (* Significant: $P<0.05$; ** Very significant: $P<0.01$; *** Highly significant; $P<0.001$; NS: Not significant).

\section{Results and discussion}

The results obtained by the chemical properties evaluation show that the organic matter content of burnt soils (7.73\%) was significantly lower compared to the control zone (16.08\%) $(P<0.001)$. However, the statistical tests of the other properties do not indicate a significant difference, only a slight decrease was noticed for total limestone in the burnt soil in contrast to control zone. The average values of $\mathrm{pH}_{\mathrm{H}_{2} \mathrm{O}}$ and $\mathrm{pH}_{\mathrm{KCl}}$ approach each other in both zones.

The fire did not significantly affect the physical parameters except soil moisture. Here, a decrease of $4.89 \%$ between the burnt zone and its control zone $(P<0.05)$ was observed. In terms of permeability, retention capacity, porosity and electrical conductivity, a slight decrease was observed in burnt soils compared to control zone. Considering the bulk density and real density, an increase in both parameters was observed in the burnt zone in contrast to control zone (Table 1).
The results obtained for the biological analyses show that the basal respiration and microbial biomass were significantly lower in burnt area than in control zone $(P<0.001)$ despite the passing of two years since the fire. decrease was approx. $1.09\left(\mu \mathrm{g} \mathrm{C}-\mathrm{CO}_{2} \cdot \mathrm{g}^{-1} \mathrm{DM} \cdot \mathrm{h}^{-1}\right)$ for basal respiration and $0.19\left(\mu \mathrm{gCmic} \cdot \mathrm{g}^{-1} \mathrm{DM}\right)$ for microbial biomass.

Considering the metabolic quotient, there was a significant increase $(P<0.05)$ in burnt zone compared to control zone - values 14.59 and $8.02\left(\mathrm{mg} \mathrm{C}-\mathrm{CO}_{2} \cdot(\mathrm{g} \mathrm{Cmic})-1 \cdot \mathrm{h}^{-1}\right)$, respectively (Fig. 2).

Two years since the fire, results show that organic matter decreased significantly in the burnt soil compared to control zone. According to Verma and Jayakumar (2012), high intensity fires can result in a total loss of soil organic matter. Similarly, Annabi et al. (2009) recorded critical organic carbon values for forest soils in the semi-arid zone eight years after the last fire.

The role of organic matter as a cementing agent for soil aggregates is extremely important after a fire (Granged et al., 2011). Therefore, the higher the organic matter content in soil, the better the cohesion between soil particles, and thus higher resistance to erosion.

This deficit in organic matter is a direct result of the combination of total vegetation burning in this area and the water erosion phenomenon. Van der Werf et al. (2010) and Guenon et al. (2011) reported that fires eliminate large quantities of organic matter from ecosystems by vegetation burning and complete oxidation of soil organic matter. Furthermore, Knicker (2007) concluded that erosion and burning progressively deplete organic matter and nutrients of soil. Wind and water erosion of ash is a significant risk in recently burnt areas. In general, the wind carries them to gullies, where they accumulate and from which they are leached by runoff, causing a net loss of soil fertility (Vennetier et al., 2014).

In terms of the rest of chemical properties, the average values of the two zones (burnt and control) were getting closer, showing the absence of a significant difference. This means that either these soil properties have not been affected by the fire from the beginning, or the impact was

Table 1 Physicochemical properties of burnt and control soils

\begin{tabular}{|c|c|c|c|c|}
\hline \multicolumn{2}{|l|}{ Properties } & \multirow{2}{*}{$\begin{array}{c}\text { Burnt } \\
7.64\end{array}$} & \multirow{2}{*}{$\begin{array}{c}\text { Control } \\
7.64\end{array}$} & \multirow{2}{*}{$\begin{array}{c}\text { Signification } \\
\text { NS }\end{array}$} \\
\hline Chemical & $\mathrm{pH}_{\mathrm{H}_{2} \mathrm{O}}$ & & & \\
\hline & $\mathrm{pH}_{\mathrm{KCl}}$ & 7.40 & 7.38 & NS \\
\hline & organic matter (\%) & 7.73 & 16.08 & $* * *$ \\
\hline & total limestone (\%) & 15.80 & 20.98 & NS \\
\hline \multirow[t]{7}{*}{ Physical } & bulk density $\left(\mathrm{g} \cdot \mathrm{cm}^{-3}\right)$ & 1.23 & 1.05 & NS \\
\hline & real density $\left(\mathrm{g} \cdot \mathrm{cm}^{-3}\right)$ & 2.42 & 2.39 & NS \\
\hline & total porosity (\%) & 49.17 & 56.07 & NS \\
\hline & moisture (\%) & 3.33 & 8.22 & * \\
\hline & retention capacity (\%) & 61.20 & 79 & NS \\
\hline & permeability $\left(\mathrm{cm} \cdot \mathrm{h}^{-1}\right)$ & 2.63 & 2.74 & NS \\
\hline & electrical conductivity $\left(\mathrm{dS} \cdot \mathrm{m}^{-1}\right)$ & 0.18 & 0.22 & NS \\
\hline
\end{tabular}



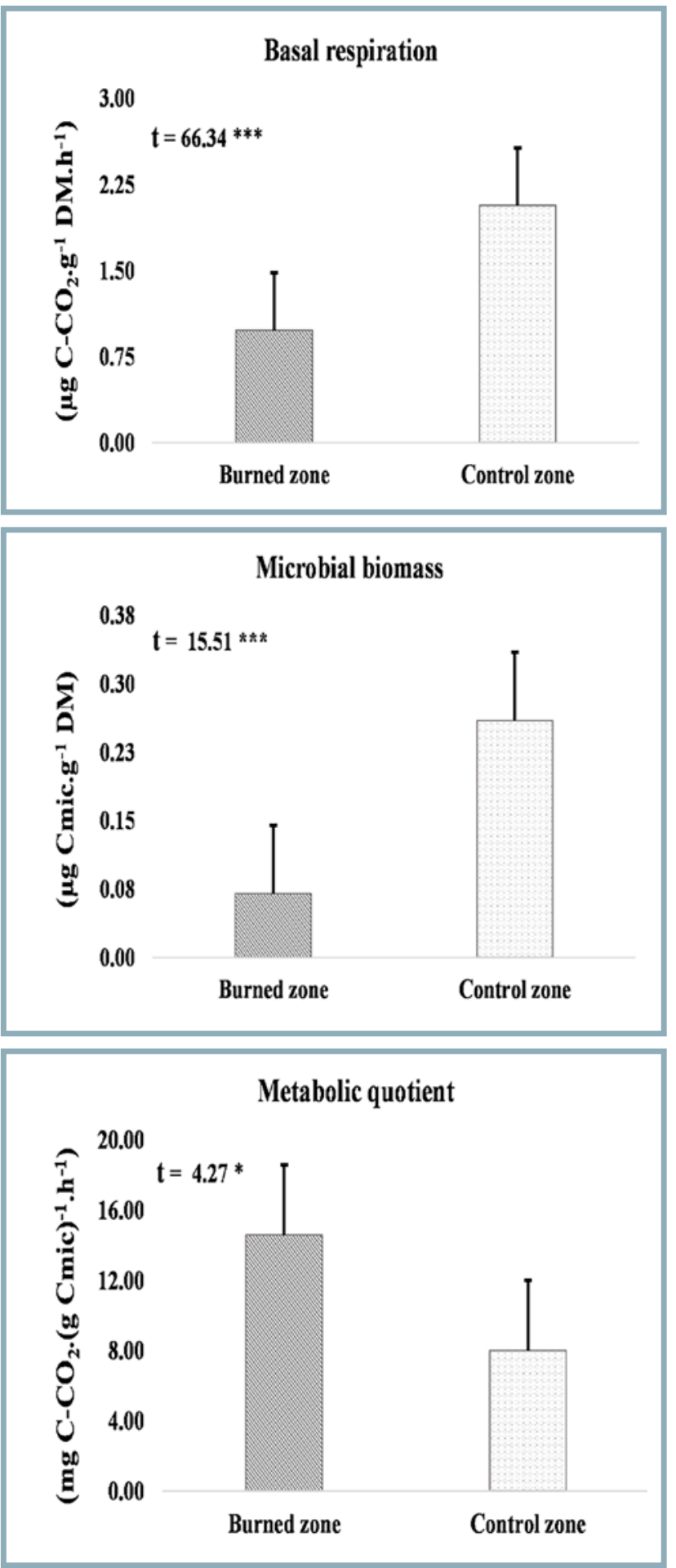

Fig. 2 Variation in biological properties in burnt and control soils particularly significant during the first months after the fire, and over time, the differences between the two zones gradually disappeared.

Study results indicate that after two years since the last fire, the physical properties of these soils were not significantly affected with exception of the moisture - there was a decrease in this value in the burnt zone compared to control zone. The results obtained corroborate those obtained by Mabuhay et al. (2006), who reported that after thirteen months, the soil moisture content was significantly higher in the unburnt site in contrast to the burnt site. Moreover, Holden et al. (2013) reported a decrease in soil moisture after the fire.

The decrease in soil moisture is due to absolute destruction of trees protecting the soil against the direct effect of solar radiation, and their replacement by the herbaceous stratum, which increases the use of water in the superficial horizon. This will accentuate evapotranspiration in burnt soils. Mulumba and Lal (2008) demonstrated the relationship between the soil organic matter and moisture: they observed that moisture increases in soils containing higher amount of organic matter, which comes from plant residues.

Considering the other physical properties, there were only slight differences between the two areas, but these were not statistically significant. Bulk density and real density increased in burnt soils in contrast to control zone; this increase in density reduced the porosity, permeability and retention capacity in burnt soils.

After two years since fire, basal respiration and microbial biomass in burnt soils remained lower in all cases compared to the control zone. Therefore, the effect of this constraint on the soil biological properties can persist for multiple years after the fire passage. According to the results obtained by Holden and Treseder (2013), microbial reactions were significantly negative after fires, a reduction in microbial biomass was positively correlated with low values of microbial respiration. After the fires, Smith et al. (2008) observed a reduction in microbial biomass and diversity of microorganisms. Furthermore, Barcenas et al. (2011) reported that soil respiration decreased to lower values in contrast to unburnt reference site thirty-two months after the fire.

This decrease in basal respiration and microbial biomass was due to low rate of organic matter and moisture in these burnt soils, which prevented the rapid maintenance of microbial communities. Papa et al. (2008) suggested that a low moisture and high temperatures can be considered the most important factors affecting soil biological activities in Mediterranean ecosystems.

The metabolic quotient is used as an indicator of the physiological state of soil microorganisms. It shows how efficiently microorganisms use the available carbon in soil for their biosynthesis (Anderson, 2003). Fließbach et al. (2007) suggested that high values of $q \mathrm{CO}_{2}$ reflect the growing microbial communities with high energy needs to sustain themselves, while low values of $q \mathrm{CO}_{2}$ indicate less disturbed soils, harbouring communities, more diversified communities with more prominent mutual interactions. 
Statistical analysis shows that the metabolic quotient in the burnt zone was significantly higher compared to the control zone. Therefore, the fire has a negative impact on the microbial community metabolic efficiency. This confirms our results (decrease of basal respiration and microbial biomass) and shows that the microbial population of these soils is still stressed and affected by the fire even after two years of its passage.

\section{Conclusion}

Forest fires are one of the most widespread factors responsible for the degradation of forest ecosystems in the world, especially their frequency poses a permanent threat to the already fragile biodiversity in the Mediterranean basin. In this study, changes in the physicochemical and biological properties of forest soils after two years since the last fire were evaluated.

The results of the physicochemical properties show that, after two years since the last fire, only the soil organic matter content and soil moisture are significantly affected with lower rates in the burnt area in contrast to control zone. A slight decrease in permeability and water retention capacity is caused by a reduction in porosity resulting from the increase in bulk and real density. Considering the rest of the chemical properties, the recorded values were almost similar, indicating the absence of a significant difference between the two zones.

In terms of biological properties, the burnt zone showed lower rates of basal respiration and microbial biomass compared to unburnt zone. The metabolic quotient was significantly higher in the burnt zone in comparison to control zone, indicating persistent disturbance of the microbial community in these soils.

\section{Acknowledgement}

All thanks are addressed to the team of the two research laboratories (Water Resources and Environment, University of Dr Moulay Tahar, Saïda, Algeria, and the Faculty of Sciences and Technologies of Saint-Jerome, Mediterranean Institute of Biodiversity and Ecology, University of Aix-en-Provence, Marseille, France), for the support and contribution to the realization of this study.

\section{References}

ANDERSON, J. P. E. - DOMSCH, K. H. 1978. A physiological method for the quantitative measurement of microbial biomass in soils. In Soil Biology and Biochemistry, vol. 10, no. 3, pp. 215-221.

ANDERSON, T. H. 2003. Microbial eco-physiological indicators to asses soil quality. In Agriculture, Ecosystems \& Environment, vol. 98, no. 1-3, pp. 285-293.

ANNABI, M. - BAHRI, H. - LATIRI, K. 2009. Organic status and microbial respiration of soils in northern Tunisia. In Biotechnology, Agronomy, Society and Environment, vol. 13, no. 3, pp. 401-408. (In French: Statut organique et respiration microbienne des sols du nord de la Tunisie).

BARCENAS, M. G. - GARCIA, O. F. - MATAIX, S. J. - MATAIX, B. J. - BÅÅTH, E. 2011. Soil microbial recolonisation after a fire in a Mediterranean forest. In Biology and Fertility of Soils, vol. 47, no. 3, pp. 261-272.
BEARE, M. H. - NEELY, C. L. - COLEMAN, D. C. - HARGROVE, W. L. 1990. A substrate-induced respiration (SIR) method for measurement of fungal and bacterial biomass on plant residues. In Soil Biology and Biochemistry, vol. 22, no. 5, pp. 585-594.

BLAKE, G. R. - HARTGE, K. H. 1986. Part 1. Bulk density in physical and mineralogical methods. In: KLUTE, A. ( $2^{\text {nd }}$ eds). Methods of Soil Analysis. American Society of Agronomy, Soil Science Society of America, Madison, Wisconsin USA, pp. 363-382. doi:10.2136/ sssabookser5.1.2ed.c13.

BORSALI, A. H. 2013. Contribution to the assessment of the impact of fires on forest ecosystems: case of Fénouane Forest, Ain El Hadjer town, Saida Province, Algeria. Doctoral dissertation, University of Aix-Marseille, 200 pp. (In French: Contribution à l'évaluation de l'impact des incendies sur les écosystèmes forestiers: cas de la Forêt de Fénouane, Commune d'Ain El Hadjer, Wilaya de Saida, Algérie).

CERTINI, G. 2005. Effects of fire on properties of forest soils: a review. In Oecologia, vol. 143, no. 1, pp. 1-10.

EAMUS, D. - MACINNIS-NG, C. M. - HOSE, G. C. - ZEPPEL, M. J. - TAYLOR, D. T. - MURRAY, B. R. 2005. Ecosystem services: an ecophysiological examination. In Australian Journal of Botany, vol. 53, no. 1, pp. 1-19.

FLIEßBACH, A. - OBERHOLZER, H. R. - GUNST, L. - MÏDER, P. 2007. Soil organic matter and biological soil quality indicators after 21 years of organic and conventional farming. Agriculture. In Ecosystems \& Environment, vol. 118, no. 1-4, pp. 273-274.

GONGALSKY, K. B. - MALMSTRÖM, A. - ZAITSEV, A. S. - SHAKHAB S. V. - BENGTSSON, J. - PERSSON, T. 2012. Do burned areas recover from inside? An experiment with soil fauna in a heterogeneous landscape. In Applied Soil Ecology, vol. 59, pp. 73-86.

GRANGED, A. J. - JORDAN, A. - ZAVALA, L. M. - MUÑOZ-ROJAS, M. MATAIX-SOLERA, J. 2011. Short-term effects of experimental fire for a soil under eucalyptus forest (SE Australia). In Geoderma, vol. 167, pp. 125-134.

GUENON, R. - VENNETIER, M. - DUPUY, N. - ZIARELLI, F. - GROS, R. 2011. Soil organic matter quality and microbial catabolic functions along a gradient of wildfire history in a Mediterranean ecosystem. In Applied Soil Ecology, vol. 48, no. 1, pp. 81-93.

HART, S. C. - DELUCA, T. H. - NEWMAN, G. S. - MACKENZIE, M. D. - BOYLE, S. I. 2005. Post-fire vegetative dynamics as drivers of microbial community structure and function in forest soils. In Forest Ecology and Management, vol. 220, no. 1-3, pp. 166-184.

HOLDEN, S. R. - GUTIERREZ, A. - TRESEDER, K. K. 2013. Changes in soil fungal communities, extracellular enzyme activities, and litter decomposition across a fire chronosequence in Alaskan boreal forests. In Ecosystems, vol. 16, no. 1, pp. 34-46.

HOLDEN, S. R. - TRESEDER, K. K. 2013. A meta-analysis of soil microbial biomass responses to forest disturbances. In Frontiers in Microbiology, vol. 4, pp. 163.

KNICKER, H. 2007. How does fire affect the nature and stability of soil organic nitrogen and carbon? A review. In Biogeochemistry, vol. 85 , no. 1, pp. 91-118.

MABUHAY, J. A. - NAKAGOSHI, N. - ISAGI, Y. 2006. Soil microbial biomass, abundance, and diversity in a Japanese red pine forest: first year after fire. In Journal of Forest Research, vol. 11, no. 3, pp. 165-173.

MATHIEU, C. - PIELTAIN, F. 1998. Physical analysis of soils. Selected methods. Montpellier, France: Research Institute for Development, 275 pp. ISBN 2-7430-0283-2. (In French: Analyse physique des sols: méthodes choisies).

MEDDOUR, S. O. 2014. Forest fires in Algeria: Risk analysis, study of causes, evaluation of the defense system and management politics. PhDThesis in Agricultural Sciences, University of Mouloud Mammeri Tizi Ouzou, 256 pp. (In French: Les feux de forêt en Algérie: Analyse du risque, étude des causes, évaluation du dispositif de défense et des politiques de gestion). 
MULUMBA, L. N. - LAL, R. 2008. Mulching effects on selected soil physical properties. In Soil and Tillage Research, vol. 98, no. 1, pp 106-111.

NOURAEIN, M. - KOUCHAK-KHANI, H. - JANMOHAMMADI, M. MOHAMADZADEH, M. - ION, V. 2020. The effects of tillage and fertilizers on growth characteristics of Kabuli chickpea under Mediterranean conditions. In Acta Technologica Agriculturae, vol. 23, no. 1, pp. 18-23.

PAPA, S. - PELLEGRINO, A. - FIORETTO, A. 2008. Microbial activity and quality changes during decomposition of Quercus ilex leaf litter in three Mediterranean woods. In Applied Soil Ecology, vol. 40, no. 3, pp. 401-410.

PAYCHENG,C. 1980. Analyticalmethods used attheDakarLaboratory. Nouméa, French: ORSTOM, 109 pp. http://horizon.documentation. ird.fr/exl-doc/pleins textes/divers10-09/010005303.pdf (In French: Méthodes d'analyses utilisées au laboratoire commun de Dakar).

PÉTARD, J. 1993. Soil analysis: Methods of analysis (volume 1). Nouméa, French: ORSTOM, 192 pp. ISBN 010005303. (In French: Les méthodes d'analyses: tome 1. Analyse de sols).

SABAGHNIA, N. - JANMOHAMMADI, M. 2014. Evaluation of selection indices for drought tolerance in some chickpea (Cicer arietinum L.) genotypes. In Acta Technologica Agriculturae, vol. 17, no. 1, pp. 6-12.

SAETRE, P. 1998. Decomposition, microbial community structure, and earthworm effects along a birch-spruce soil gradient. In Ecology, vol. 79, no. 3, pp. 834-846.

SMITH, N. R. - KISHCHUK, B. E. - MOHN, W. W. 2008. Effects of wildfire and harvest disturbances on forest soil bacterial communities. In Applied and Environmental Microbiology, vol. 74, no. 1, pp. 216-224.

SMS. 2017. Climatic data. Saïda Meteorological Station.

UROZ, S. - BISPO, A. - BUÉE, M. - CEBRON, A. - CORTET, J. - DECAENS T. - HEDDE, M. - PERES, G. - VENNETIER, M. - AND VILLENAVE, C. 2014. Overview of advances in the field of forest soil biology. In French Forest Review, vol. 66, no. 4, pp. 467-477. (In French: Aperçu des avancées dans le domaine de la biologie des sols forestiers).
VAN DER WERF, G. R. - RANDERSON, J. T. - GIGLIO, L. - COLLATZ, G. J. - MU, M. - KASIBHATLA, P. S. - VAN LEEUWEN, T.T. 2010. Global fire emissions and the contribution of deforestation, savanna, forest, agricultural, and peat fires (1997-2009). In Atmospheric Chemistry and Physics, vol. 10, no. 23, pp. 11707-11735.

VENNETIER, M. - CECILLON, L. - GUENON, R. - SCHAFFHAUSER, A. VERGNOUX, A. - BOICHARD, J. L. - MASION, A. - BOTTÉRO, J.Y. - RUY, S. - DOUSSAN, C. - GAUDU, J. C. - RENARD, D. - CURT, T. - FAIVRE, N. RIPERT, C. - ESTĖVE, R. - MARTIN, W. - MAS, C. - MORGE, D. - BRUN, J. J. - JUVY, B. - CASSAGNE, N. - MERMIN, E. - TARDIF, P. - FAVIER, G. DE DANIELI, S. - GROS, R. - TATONI, T. - CARRARA, M. - DOUMENQ, P. - GUILIANO, M. - MILLE, G. - MALLERET, L. - LEBARRILLER, S. - ASIA, L. - DOMEIZEL, M. - VASSALO, L. - MASSIANI, C. - THÉRAULAZ, F. DI ROCCO, R. - CZARNES, S. - CLAYS-JOSSERAND, A. - COMMEAUX C. - DEGRANGE, V. - GUILLAUMAUD, N. - LE ROUX, X. - POLY, F. HOEPFFNER, M. - PIGNOT, V. - CHANDIOUX, O. 2008. Study of the impact of repeated forest fires on biodiversity and soils: search for indicators. Final report, CEMAGREF, Ministry of Agriculture and Fisheries, European Union, Aix en Provence, 236 pp. (In French: Etude de l'impact d'incendies de forêt répétés sur la biodiversité et sur les sols: recherche d'indicateurs).

VENNETIER, M. - LADIER, J. - REY, F. 2014. Control of forest soil erosion by vegetation in the face of global changes. In French Forest Review, vol. 66, no. 4, pp. 467-478. (In French: Le contrôle de l'érosion des sols forestiers par la végétation face aux changements globaux).

VERMA, S. - JAYAKUMAR, S. 2012. Impact of forest fire on physical, chemical and biological properties of soil. In Review, Proceedings of the International Academy of Ecology and Environmental Sciences, vol. 2, no. 3, pp. 168-176. 